\title{
Motivating Salespeople to Contribute to Marketing Intelligence Activities: An Expectancy Theory Approach
}

\author{
Wadie Nasri \\ Assistant Professor of Management, Higher Institute of Management of Gabes \\ University of Gabes, ISG Gabès, Street Jilani Al Habib, 6000, Gabes, Tunisia \\ E-mail: wdnasri@gmail.com \\ Lanouar Charfeddine \\ Assistant Professor, Quantitatives Methods Department, Higher Institute of Management of Gabes \\ University of Gabes, BP 75, ISG Gabès, Street Jilani Al Habib, 6000, Gabes, Tunisia \\ Tel: 216-5-2299-8570_E-mail: Lanouar_charf@yahoo.fr
}

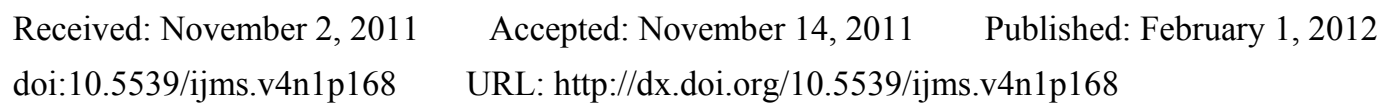

\begin{abstract}
This study was to investigate the motivational factors that may contribute to explain salespeople's motivation toward marketing intelligence activities. The proposed conceptual model utilizes expectancy theory, a process theory of motivation. Three factors can motivate salesperson to exert effort to collect and transmit information from the field expectancy, instrumentality and valence. The proposed conceptual model provides a manager a better understanding that salespeople will motivated and given amount effort to contribute marketing intelligence activities if he or she will gather good information about competitors or about customers and receive a reward for the information transmitted, which he or she really want to obtain.
\end{abstract}

Keywords: Sales force, Marketing information system, Marketing intelligence, Motivation, Expectancy theory

\section{Introduction}

A marketing information system is a continuing and interacting structure of people, equipment and procedures to gather, sort, analyse, evaluate, and distribute pertinent, timely and accurate information for use by marketing decision makers to improve their marketing planning, implementation, and control (Kotler, 2002). Marketing information system can be decomposed into: the internal reporting systems, marketing research system, marketing intelligence system and marketing models.

The marketing intelligence system is a set of procedures and data sources used by marketing managers to sift information from the environment that they can use in their decision making. Therefore, marketing intelligence system provides a continuous flow of information about new technologies, markets, customers, and the economic and regulatory environment that might affect the company's position.

Salespersons are in an excellent position to garner external information and transfer it to their organization (Lorge, 1998). In some instances, the sales force can provide information about the marketing environment that is unavailable via other means (Grove, 1992).

Salespeople have long been recognized as primary sources of marketing intelligence (Webster, 1965). Because of their position, salespeople can observe, filter, and transmit information about the sales environment to aid managerial decisions (Grove, 1992). Due to their frequent contact with customers and competitors, salespeople can generate a flow of information, such as needs, wants, and preferences of the customers which will help executives make better decision (Mellow, 1989). Mellow (1989), observed that salespeople are likely source of information about marketplace problems.

Among the earliest researchers to highlight the advantages of using the salesperson as an information source was Webster (1965). He suggested that sales personnel could serve as a good source of information because: (1) the salesperson has a close relationship with customers and knows their needs and wants, (2) the customer will 
provide the information to the salesperson whom he or she regards as a problem solver, (3) the costs of gathering the information are low, and (4) providing this information requires very little additional effort on the part of the salesperson. In addition, sales representatives may have access to some information about their customers that would not be available from any other source.

Collecting and transmuting market information has been ranked fourth out of the ten most important missions of a salesperson in the industrial sector (Moncrief, 1986). Moreover, the majority of authors conclude that the benefits from incorporating the sales force in the marketing research function will greatly exceed the associated costs (Douglas, 1990) and the information reported by salespeople could enable the firm to refine its marketing mix and/or develop new products that are tailored to its target market (Douglas, 1990).

Despite the successfully role of salespeople in the collect and transmitting of intelligence and in contribution to the marketing information system (Fouss et Solomon, 1980; Grace et Pointon, 1980; Lambert et al., 1990; Chonko et al., 1991), little research has been directed to understand and explain behavior salespeople's toward this specific task (Roberston, 1974; Wotruba et Mongone, 1979; Thiétart et Vivas, 1981; Evans et Schlacter, 1985; Festervand et al., 1988; Craven et al., 1993; Le Bon, 1997; Le Bon, 2006; Le Bon et Merunka, 2006).

Using the salesforce as strategic information source may present difficulties to mobilize the salesforce to engage in marketing intelligence activities (Darmon, 1992, Goodman, 1971, Thiétart et Vivas, 1981). In fact, the main problem lies in changing attitude and motivating the salesman's for looking and transmitting strategic information.

Motivation is the key factor in influencing humans to work better, so an increase in motivation will result in higher productivity and more profit, which is the ultimate goal of the construction industry.

Understanding and having knowledge about motivation theories can help to create a motivational atmosphere, and application of these theories can result in achieving higher productivity (Hassen, 2005).

In Churchill et al.'s (1985) meta-analysis of sales performance, motivation was found to be the third most effective predictor of sales performance after role perceptions and skills. In this context, expectancy theory is the most general theory of motivation and is the most common basis for salesforce motivation studies to explain salespeople's performance in various aspects of their job (Churchill et al, 1985, Vroom, 1964, Walker et al, 1977).

Within this context, our paper has three main objectives: first, to examine the importance of salespersons in contribution to marketing intelligence activities, second, to analyse the importance of motivational factors on salesperson's contribution to marketing intelligence activities, and third to explain salesperson's motivation using the expectancy theory.

This paper is structured into four sections including this introduction section. The second section concerns the literature review on motivation especially expectancy theory motivation. The third section, presents the conceptual model of motivation of salespeople's to gather and transmit information from the field. The fifthly section consists section concludes by implications for theory and practice, the limitation and avenues for future research.

\section{Theoretical background}

\subsection{Review of motivation concept}

Motivation is the psychological process that drive them physiologically and psychologically to pursue one or more goals to fulfill their needs or expectations (Stev, 2003). Motivation as defined by Robbins (1993) is the willingness to exert high level of effort toward organizational goals, conditioned by the effort's ability to satisfy some individual need.

Motivator's factors may be intrinsic or extrinsic. An example of an intrinsic motivator factor is the self-fulfillment of a worker as a result of performing a task well. An example of an extrinsic motivator factor is the reward of monetary bonus for extra effort input by a worker. Most of the theorists assert that intrinsic motivators are better than extrinsic ones. A number of theories have been proposed to explain individual motivation to perform work. These theories fall into basically two categories, content and process theories.

\subsubsection{Content theories of motivation}

The first categories of theories assume that factors exist within the individuals that energize, direct, and sustain behavior. They are concerned with the identification of important internal elements and the explanation of how these elements motivate persons. Maslow's Hierarchy of Needs Theory), classifies the desires or needs of human beings in five needs: physiological, safety, social, esteem, and self-actualization and must satisfy lower-level 
needs before we seek to satisfy higher-level needs. Two-factor theory (Herzberg et al, 1959) divides work factors into motivation factors (those that are strong contributors to job satisfaction) and hygiene factors (those that, though not strong contributors to satisfaction must be present to prevent job dissatisfaction). To increase satisfaction (and motivate someone to perform better), managers must address motivation factors. Douglas McGregor proposed two theories by which to view employee motivation. Theory $\mathrm{X}$ advanced that average employees' dislike work, and can only be made to get results at work by supervising the employees closely, and motivating them in short term through financial incentive schemes. Theory Y assumes that average employees' desire self-direction and self-control, seek and accept responsibility, enjoy physical and mental effort, and have the potential to be self-motivating.

\subsubsection{Process theories of motivation}

The second categories attempt to describe how behavior is energized, directed, and sustained. They focus on certain psychological processes underlying action and place heavy emphasis on describing the functioning of the individual's decision system as it relates to behavior. Equity and expectancy theories offer compatible frameworks for understanding work motivation.

Adams' equity theory (Adams, 1963) is a prevalent theory of distributive justice that is introduced in most management and nearly all organizational behavior textbooks as a major theory of work motivation.

Expectancy theory originally developed by Vroom (1964) and has served as a theoretical foundation for a large body of studies in psychology, education, organizational behavior, and management accounting (Harrell et al, 1985; Brownell and McInnes, 1986; Hancock, 1995; Snead and Harrell, 1995; Geiger and Cooper, 1996). It has been recognized as one of the most promising conceptualizations of individual motivation (Ferris, 1977).

According to the expectancy theory the choice of the amount of effort people exert is based on a systematic analysis of (a) the values of the rewards from these outcomes, (b) the likelihood that rewards will result from these outcomes, and (c) the likelihood of attaining these outcomes through their actions and efforts (Chen et al, 2006). Expectancy theory identifies three factors which play an interactive role in motivation (Vroom, 1964).

The first factor, effort - performance expectancy, concerns the individual's perception that effort is positively correlated with level of performance. The second factor in expectancy theory, performance-outcome expectancy, or instrumentality, concerns a person's expectations that the rewards he will receive are closely tied to his level of performance. Valence, the degree to which an individual values a particular reward, is the third component of expectancy theory. The more a person values the reward she will receive for her effort, the more motivated she will be to receive the reward. Rewards for which people generally have a high valence include salaries, bonuses, promotions, and recognition. Nevertheless, different individuals will value certain rewards differently. This theory can be used to predict the motivational consequences not only on pay changes, but also for promotions, changes in working conditions and assignments, use of overtime, training, and recognition of achievements, to name a few (Warren, 1989).

\subsection{Expectancy theory: A conceptual model of motivation of salespeople's to contribuate to marketing intelligence activities}

Expectancy theory generally is supported by empirical research (Tien, 2000; Vansteenkiste et al., 2005) and is one of most commonly used theories of motivation in the workplace (Campbell and Pritchard, 1976; Heneman and Schwab, 1972; Mitchell and Biglan, 1971). Expectancy theory provides a general framework for assessing, interpreting, and evaluating employee behaviour in learning, decision-making, attitude formation, and motivation (Chen and Lou, 2002). The use of expectancy theory to understand sales force motivation has produced a considerable amount of research over the past two decades (Evanset al, 1982; Johnston and Kim, 1994; Oliver, 1974; Teas, 1981; 1982; Teas and McElroy 1986; Tyagi 1982; Walker, et al, 1977). Expectancy theory is based on the assumption that salespeople have expectancy about what they should receive from organization a result of their work efforts.

Expectancy theory models motivation as a function of the (salesperson's) expectation that a given action will result in certain performance, along with the perceived instrumentality of that performance for achieving various outcomes and the valence of those outcomes (Vroom, 1964). Mathematically, expectancy theory can be synthesized as follows:

$$
\mathrm{M}=\mathrm{E} * \Sigma(\mathrm{V} * \mathrm{I})
$$




\subsubsection{Expectancy (E)}

Belief about the link between trying to perform a behavior it well refers to persons' expectancy about the future. Expectancy, then, is the salesperson's estimate of the probability that expending

A given amount of effort to contribute in this task will lead to an improved level of performance on some dimension. As show in figure 1, the first important question that salespeople ask themselves is "If I exert effort to gather good information about competitors or about customers, what is the probability that my sales performance will improve?" Should the answer be "high", they are more likely to given more effort to contribute to marketing intelligence activities. There are variables that affect salesperson's expectancy perception. These variables include self-efficacy (a salesperson's belief in their ability to gather and transmit intelligence from the field), goal difficulty (how attainable is this goal), and control (does the salesperson actually have control over the expected outcome).

\subsubsection{Instrumentality (I)}

In expectancy theory, the salesperson's estimate of the probability that achieving and improved level of performance on gathering and transmitting good information from the field, will lead to increase attainment of particular rewards or outcome may be defined instrumentality. The second question that salespeople asked themselves might be "Will I be rewarded if I gather and transmit good information about competitors or about customers" Task, for example, the salesperson on straight salary, the salesperson might ask "If I gather and transmit good information about competitors or customers, what is the probability that I will get added pay?" The instrumentality component of expectancy theory is the salesperson's belief that if they can meet performance expectations, they will receive "a great reward". Several variables can affect instrumentality such as trust (in leaders), control, and policies (how formalized are rewards systems in written policies?).

\subsubsection{Valence (V)}

Valence for reward refers to the degree to which a salesperson values a particular reward for improved performance. The third important question that salespeople ask themselves is "Are the rewards worth it" Conceptual distinction between extrinsic and intrinsic rewards. Extrinsic outcomes are those rewards that are distributed by some external agent (for example, annual bonus for performing a job, pay and promotion) while intrinsic outcomes are mediated by the individual and are internal, personal rewards (for example, joy from performing a job, feelings of achievement and self-fulfilment, self-actualisation, self-determination and competence). Graen (1969) and Mitchell and Albright (1972) have suggested that intrinsic rewards are superior to those yielded by extrinsic outcomes. Other authors (Wahba and House, 1974) have suggested that intrinsic rewards may have more power to motivate than extrinsic rewards, primarily because the instrumentality perceptions associated with outcomes that are self-administered should approach certainty. Parker and Dyer (1976) noted that the roles of intrinsic and extrinsic outcomes in expectancy theory research are very complex and agreement about their roles remains very much unsettled.

\section{Conceptual model}

Expectancy theory states that a salesperson will exert a certain amount of effort toward marketing intelligence activities if he or she estimates that the effort will lead to a specific performance (expectancy: probability of being successful after an effort), witch will imply a real reward (instrumentality: probability of a performed effort being recognized within the company) that he or she really desires (the perceived value of the rewards).

The model adopted for the remainder of the paper is based on a model developed by Vroom (1964). As mentioned in figure1, salesperson will be motivated and given amount effort to contribute in this task if he or she will gather good information about competitors or about customers from interaction with customer (expectancy) and receive a reward for the information transmitted (instrumentality), which he or she really want to obtain (valence).

Based on the literature review, the model of salesperson motivation to contribute to marketing intelligence activities was developed using the expectancy theory. Thus, hypotheses were proposed as follows:

H1: Expectancy has a positive effect on salespeople's motivation toward marketing

H2: Instrumentality has a positive effect on salespeople's motivation toward marketing

H3a: Extrinsic valence has a positive effect on salespeople's motivation toward marketing.

$\mathrm{H} 3 \mathrm{~b}$ : Intrinsic valence has a positive effect on salespeople's motivation toward marketing. 


\section{Conclusion, implication and future study}

The purpose of this study was to investigate what might motivate salesforce to engage in marketing intelligence activities. Vroom's model of expectancy theory formed the basis of the investigation. This study develops a theoretical and managerially important model linking effort toward intelligence activities and expectancies.

From a theoretical standpoint this theory suggests that salesperson will be motivated to look for information in the field, if he or she feels that he or she will gather good information about competitors or about customers (expectancy) and thereby, receive a reward associated with the information transmitted (instrumentality), which he or she really wants to obtain (valence for reward).

From a managerial standpoint, the study presents insights into three important areas for managers who are responsible for developing marketing intelligence activities. First, increase expectancies. Provide a work environment that facilitates the best performance and set realistically attainable performance goals. Expectancies can usually be enhanced by providing proper equipment and training, demonstrating correct work procedures, explaining how performance is evaluated, and listening to salesperson's performance problems in collecting and transmitting marketing intelligence. Second, make performance instrumental toward positive outcomes. Make sure that good performance is followed by personal recognition, pay increase, and other positive results. Managers should also attempt to ensure that the paths between effort-performance are clear. Salespeople should be convinced that first-level outcomes desired by the organization are clearly instrumental in obtaining positive second-level outcomes and avoiding undesirable outcomes. Third, identify positively valent outcome. Understand what salespeople want to get out of their work. Think about what their jobs provide them and what is not, but could be, provided consider how people may differ in the valences they assign to outcomes.

This study is the first to use expectancy theory in explaining motivation of salespeople's toward marketing intelligence activities. It was entirely review of literature in nature, and further research is needed to validate empirically the proposed conceptual model.

In our future research, we will investigate the model in the direction of the analysis of the impact of expectancy, Instrumentality, Extrinsic Valence, Intrinsic Valence on Motivation of salespersons toward marketing intelligence activities. An empirical research will be carried out to confirm the proposed conceptual model (links from the model between constructs). Additional research opportunities will be undertaken, such as identifying others factors may be influence salespeople's motivation and behaviour toward marketing intelligence, such as individual, managerial, and environmental factors can be included in the proposed conceptual model.

\section{References}

Adams, J. S. (1963). Toward an understanding of inequity. Journal of Abnormal and Social Psychology, 67(3), 422-436. http://dx.doi.org/10.1037/h0040968

Brownell, P., and McInnes M. (1986). Budgetary participation, motivation, and managerial performance. The Accounting Review, 61(October), pp.587-600.

Chen, Y., Gupta A., \& Hoshower L. (2006). Factors That Motivate Business Faculty to Conduct Research: An Expectancy Theory analysis. Journal of Education for Business, 81, 4, 179-189. http://dx.doi.org/10.3200/JOEB.81.4.179-189

Chen, Y., \& Lou, H. (2002). Toward an understanding of the behavioural intention to use a groupware application. Journal of End User Computing, 14, 1-16. http://dx.doi.org/10.3200/JOEB.81.4.179-189

Chonko, L., Tanner J., \& Smith E. (1991). Selling and Sales Management in Action: The Sales force's Role in International Marketing Research and Marketing Information System. Journal of Personnal Selling and Sales Management, 11, 1, 69-79.

Churchill, Gilbert A., Jr., Neil, M. Ford, Steven W. Hartley and Orville C. Walker (1985). The Determinants of Salesperson Performance: A Meta-Analysis. Journal of Marketing Research, 22 (May), 103-18. http://dx.doi.org/10.2307/3151357

Cravens, D., Ingram T., LaForge R., \& Young C. (1993). Behavior-Based and Outcome-Based Salesforce Control System. Journal of Marketing, 57, 4, 47-59. http://dx.doi.org/10.2307/1252218

Darmon, R.Y. (1993). Effective human resources management in the salesforce. Qurum Books, Conneticut.

Deci, Edward L. (1975). Intrinsic Motivation. New York: Plenum.

Douglas, M. L. (1990). Industrial salespeople as a source of market information, Industrial salespeople as a source of market information. Industrial Marketing Management, 19, 2, pp.141-148. 
Evans K., \& Schlacker J. (1985). The Role of Sales Managers and Salespeople in a Marketing Information System. Journal of Personnal Selling and Sales Management, 5, 3, 49-58.

Evans, K. R., Margheim, L., \& Schlacter J. L. (1982). A review of expectancy theory research in selling. Journal of Personal Selling and Sales Management, 2, 33-40.

Ferris, K. R. (1977). A test of the expectancy theory as motivation in an accounting environment. The Accounting Review, 52(3), 605-614.

Festervand, T., Grove S., \& Reibenbach E. (1988). The Sales Force as a Marketing Intelligence System. The Journal of Business and Industrial Marketing, 3, 1, 53-59. http://dx.doi.org/10.1108/eb006051

Galbraith J., and Cummings L. (1967). An empirical investigation of the motivational determinants of task performance: Interactive effects between instrumentality-valence and motivation ability. Organizational Behavior and Human Performance, 2, 237-257. http://dx.doi.org/10.1016/0030-5073(67)90020-7

Geiger, M. A., and Cooper E. A. (1996). Using expectancy theory to assess student motivation. Issues In Accounting Education, (Spring), 113-129.

Goodman, C. (1971). Management of the Personnal Selling Function. New York, Holt, Rinehart, Winston Inc.

Grace, D., and Pointon T. (1980). Marketing Research through the Salesforce. Industrial Marketing Management, 9, 1, 53-58. http://dx.doi.org/10.1016/0019-8501(80)90034-6

Grove, S., LaForge M., Knowles P., \& Stone L. (1992). Improving Sales Call Reporting for Better Management Decisions. The Journal of Consumer Marketing, 9, 4, 65-72. http://dx.doi.org/10.1108/07363769210037105

Hancock, D. R. (1995). What teachers may do to influence student motivation: An application of expectancy theory. The Journal of General Education, 44, 171-179.

Harrell, A., Caldwell, C., \& Doty, E. (1985). Within-Person Expectancy Theory Predictions of Accounting Students: Motivation to Achieve Academic Success. The Accounting Review, 60 (4), 724.

Hassen, A. H. (2005). Motivational Theories and Their Application in Construction. Cost Engineering, 47, 3, 14 -18 .

Heneman, H.G., and Schwab, E.P. (1972). Evaluation of research on expectancy predictions of employee performance. Psychological Bulletin, 78, 1-9. http://dx.doi.org/10.1108/07363769210037105

Herzberg, F., Mausner, B., and Snyderman, B. (1959). The Motivation to Work. Wiley, New York. ISO 9001:2000 Quality management systems - Requirements, International Organization for Standardization.

Johnston, Wesley J., and Keysuk Kim (1994). Performance, Attribution, and Expectancy Linkages in Personal Selling. Journal of Marketing, 58 (October), 68-81. http://dx.doi.org/10.2307/1251917

Kotler, P. (2002). Marketing management: Analysis, planning, implementation and control (11th ed.). Englewood Cliffs, New Jersey: Prentice Hall.

Lambert, D., Marmorstein H., \& Sharma A. (1990). The Accuracy of Salespersons' Perception of their Customers: Conceptual Examination and Empirical Study. Journal of Personal Selling and Sales Management, $10,1,1-9$.

Le Bon, J. (1997). Contribution des vendeurs aux activités de veille marketing et commerciale: d'un cadre conceptuel aux opportunités de recherche. Recherche et Applications en Marketing, 12, 3, 5-24.

Le Bon, J. (2006). La Force de Vente et les Activités d'Intelligence Economique. Revue Francaise de Gestion, 32, 163, 15-30. http://dx.doi.org/10.2307/1251917

Le Bon, J., and Merunka D. (2006). The impact of individual and managerial factors on salespeople's contribution to marketing intelligence activities. International Journal of Research in Marketing, 23, 4, 395-408. http://dx.doi.org/10.1016/j.ijresmar.2006.10.002

Lorge, S. (1998). Sales reps are company's best source of competitive intelligence. Sales and Marketing Management, August, pp. 76.

Maslow, A. (1954). Motivation and Personality. Harper and Row, New York.

McGregor, D. (1960). The Human Side of Enterprise. MaGraw-Hill, New York.

Mellow, C. (1989). The Best Source of Competitor Intelligence. Sales and Marketing Management, December, pp. 24-29. 
Mitchell, T.R., and Biglan A. (1971). Instrumentality theories: current uses in psychology. Psychological Bulletin, 76, 6, 432-454. http://dx.doi.org/10.1016/j.ijresmar.2006.10.002

Moncrief, W. (1986). Selling Activity and Sales Position Taxonomies for Industrial Salesforces. Journal of Marketing Research, 23, 3, 261-270. http://dx.doi.org/10.2307/3151484

Oliver, R. L. (1974). Expectancy theory predictions of salesmen's performance. Journal of Marketing Research, 11, 243-253. http://dx.doi.org/10.2307/3151484

Robbins, S.P. (1993). Organisational Behaviour. Englewood Cliffs, New.

Roberston, D. (1974). Sales Force Feedback on Competitors' Activities. Journal of marketing, 38, 2, 69 - 71.

Snead, K.C., \& Harrell, A.M. (1994). An application of expectancy theory to explain a manager's intention to use a decision support system. Decision Sciences, 25, pp. 499-513. http://dx.doi.org/10.1111/j.1540-5915.1994.tb01857.x

Steve, Y. W. Lam and Conrad, H. W. T. (2003). Motivation of Survey Employees in Construction Projects. Journal of Geospatial Engineering, Vol. 5, No.1 (June), pp. 61-66.

Teas, R. K. (1981). An empirical test of models of salespersons' job expectancy and instrumentality perceptions. Journal of Marketing Research, 18, 209-226. http://dx.doi.org/10.1111/j.1540-5915.1994.tb01857.x

Teas, R. Kenneth and James C. McElroy (1986). Causal Attribution and Expectancy Estimates: A Framework for Understanding the Dynamics of Salesforce Motivation. Journal of Marketing, 50 (January), 75-86. http://dx.doi.org/10.1111/j.1540-5915.1994.tb01857.x

Thiétart, R. A., \& Vivas R. (1981), Strategic Intelligence Activity: The Management of the Sales Force as Source of Strategic Information. Strategic Management Journal, 2, 1, 15-25. http://dx.doi.org/10.1002/smj.4250020103

Tien, F. F. (2000). To what degree does the desire for promotion motivate faculty to perform research. Research in Higher Education, 41(6), 723-752. http://dx.doi.org/10.1023/A:1007020721531

Tyagi, P. K. (1982). Perceived organizational climate and the process of salesperson motivation. Journal of Marketing Research, 19, 240-254. http://dx.doi.org/10.2307/3151624

Vansteenkiste, M., Lens W. De Witte H., and Feather N.T. (2005). Understanding unemployed people's job search behavior, unemployment experience and well-being: a comparison of expectancy-value theory and self-determination theory. British Journal of Social Psychology, 44, 2, 268-286. http://dx.doi.org/10.1348/014466604X17641

Vroom, V. C. (1964). Work and motivation. New York: Wiley.

Walker, O. C., Churchill G. A., \& Ford N. M. (1977). Motivation and performance in Industrial Selling: Present Knowledge and Needed Research. Journal of Marketing Research, 14 (May), 156-168. http://dx.doi.org/10.1348/014466604X17641

Warren, R. (1989). Motivation and Productivity in the Construction Industry. Van Nostrand Reinhold, New York

Webster, F. (1965). The industrial salesman as a source of market information. Business Horizons, 8(1), 77-82.

Wotruba, T., \& Mangone R. (1979). More Effective Sales Force Reporting. Industrial Marketing Management, 8 , 3, 236-245. http://dx.doi.org/10.1016/0019-8501(79)90007-5 


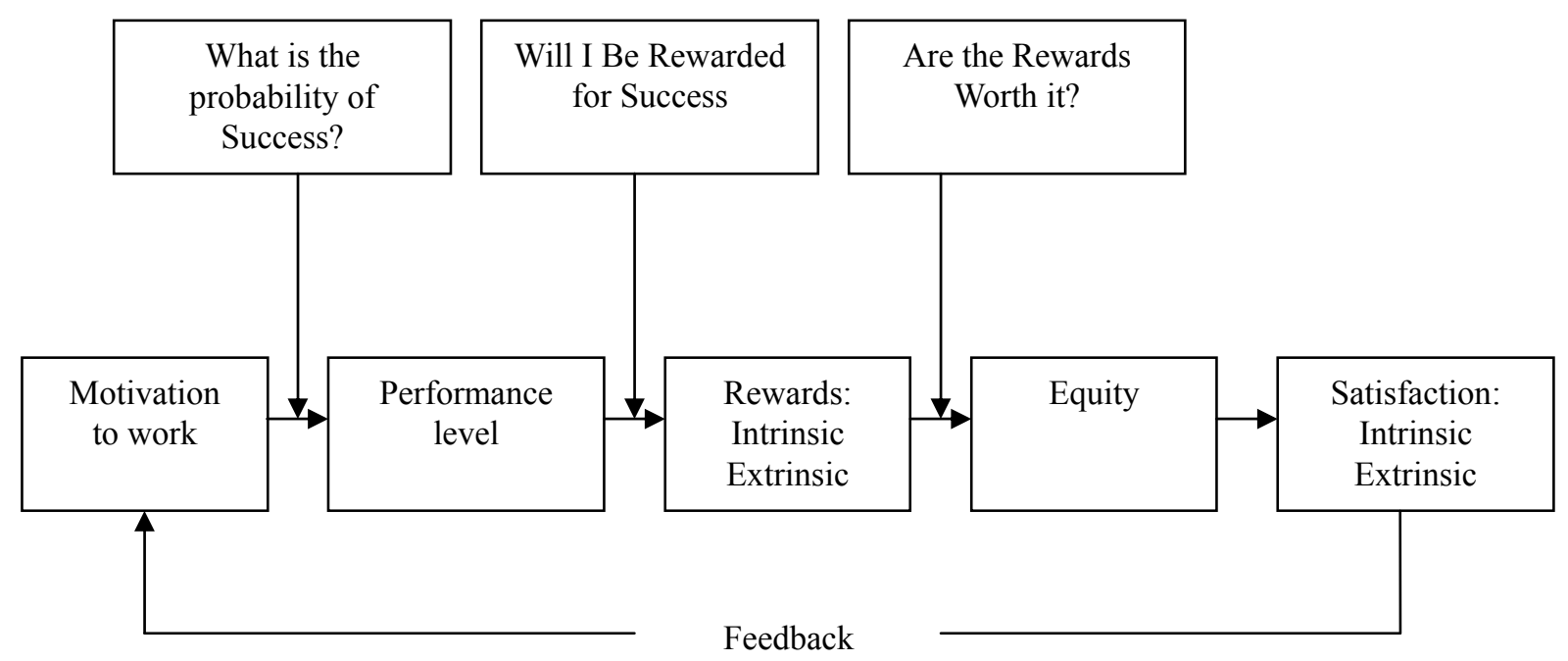

Figure 1. Three questions salespeople ask to determine how much effort they will devote to their job

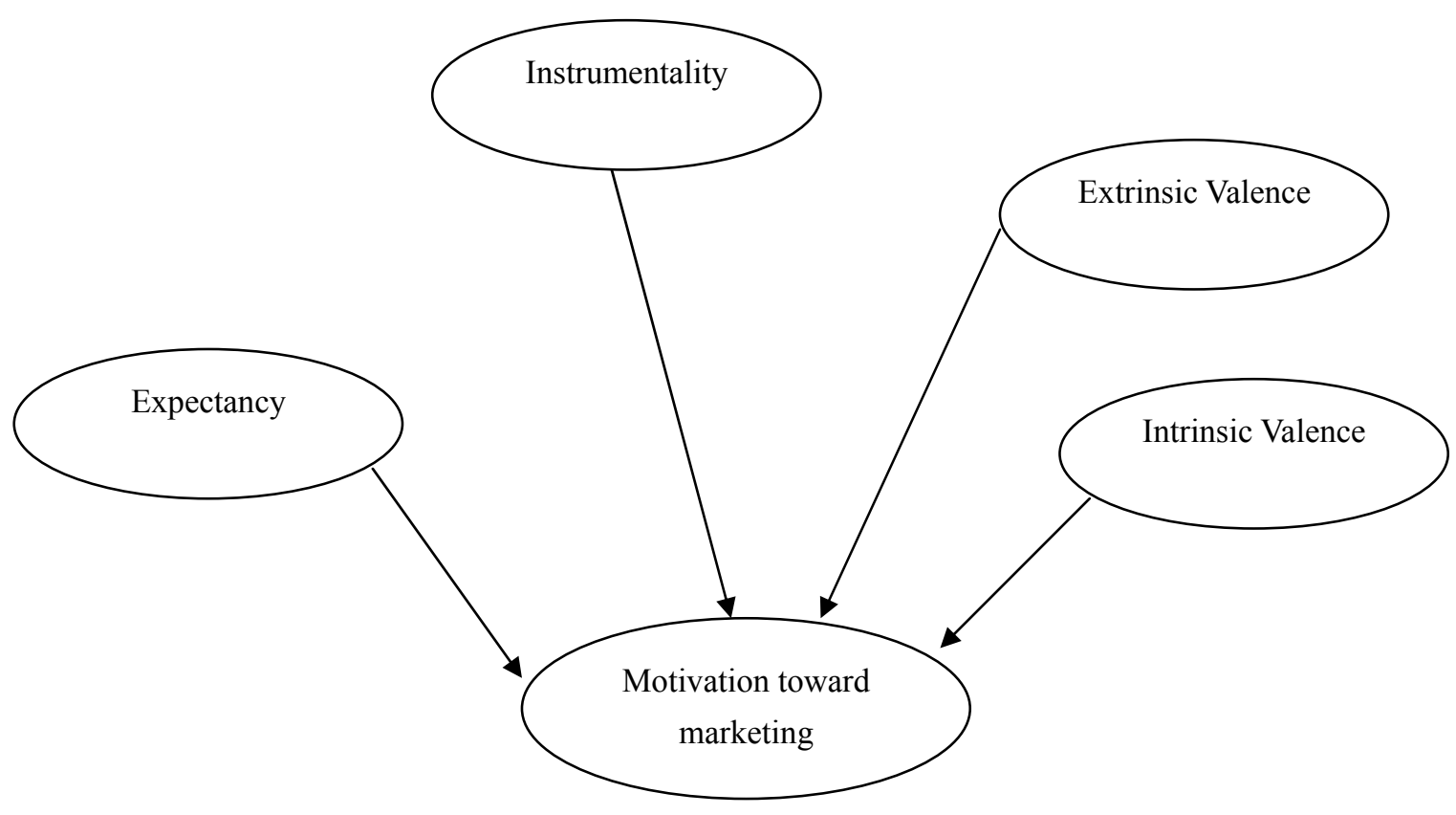

Figure 2. Conceptual model 